\title{
ANALISIS ZONASI EKOSISTEM MANGROVE PADA KAWASAN MANGROVE BEKAS TSUNAMI DI ACEH BARAT SELATAN
}

\author{
Wintah \\ Universitas Teuku Umar Meulaboh Fakultas Kesehatan Masyarakat \\ Korespondensi : syuga_2006@yahoo.co.id
}

\begin{abstract}
Mangrove zoning is influenced by environmental factors including soil texture, salinity and tides. The decline in diversity and size of mangrove forests is found in each zonation which is illustrated by changes in environmental conditions from the edge of the sea towards the land. Changes in these conditions can describe the condition of vegetation and mangrove zoning in Aceh Barat Selata. This study aims to determine the community structure of mangrove vegetation and determine the pattern of mangrove vegetation zoning in the Tsunami-Used Mangrove Area in South West Aceh. This research uses survey method and vegetation sampling technique with sampling plot. Data were analyzed to determine mangrove wealth, density and distribution. Analysis of zoning patterns using Cluster Analysis, to determine the magnitude of the contribution of each species to grouping using the Similarity Precentages analysis. Mangrove zoning on the South West Aceh Beach from the direction of the coast to the mainland is Sonneratia alba, Rhizopora apiculata, and Nipah.
\end{abstract}

Keywords: Mangrove, Zoning, Grouping

\begin{abstract}
ABSTRAK
Zonasi mangrove dipengaruhi oleh faktor-faktor lingkungan diantaranya tekstur tanah, salinitas dan pasang surut. Penurunan keanekaragaman dan ukuran hutan mangrove ditemukan di tiap zonasi yang digambarkan oleh perubahan kondisi lingkungan dari tepi laut menuju ke arah daratan. Perubahan kondisi tersebut dapat menggambarkan kondisi vegetasi dan zonasi mangrove di Aceh Barat Selata. Penelitian ini bertujuan untuk mengetahui struktur komunitas vegetasi mangrove serta mengetahui pola zonasi vegetasi mangrove pada Kawasan Mangrove Bekas Tsunami Di Aceh Barat Selatan. Penelitian ini menggunakan metode survei dan teknik pengambilan sampel vegetasi dengan plot sampling. Data dianalisis untuk mengetahui kekayaan, kepadatan dan distribusi mangrove. Analisis pola zonasi menggunakan Analisis Pengelompokan(Cluster Analisys), untuk mengetahui besarnya kontribusi masing-masing spesies terhadap pengelompokkan menggunakan analisis persentase kesamaan (Similarity Precentages). Zonasi mangrove di Pantai Aceh Barat selatan dari arah pantai menuju daratan adalah Sonneratia alba, Rhizopora apiculata, dan Nipah.
\end{abstract}

Kata Kunci: Mangrove, Zonasi, Pengelompokkan

\section{PENDAHULUAN}

Hutan mangrove terdapat zonasi yang tergantung dari adaptasi tiap jenis tumbuhan terhadap lingkungan. Daya adaptasi dari tiap jenis tumbuhan mangrove terhadap keadaan tempat tumbuh akan menentukan komposisi jenisnya. Setiap zonasi diidentifikasikan berdasarkan individu jenis mangrove atau kelompok jenis dan dinamakan sesuai dengan jenis yang dominan atau sangat melimpah. Zonasi di tepi air biasanya tipis dan ditumbuhi oleh jenis pionir, seperti Avicennia alba dan Sonneratia alba, setelah itu zona Rhizophora spp. dan kemudian zona Bruguiera spp (Hilmi, 2005).

Aceh Barat Selatan memiliki potensi hutan mangrove yang cukup besar salah satunya untuk keberlangsungan ekosistem yang ada di sekitarnya. Penelitian ini bertujuan untuk mengetahui struktur komunitas vegetasi mangrove serta mengetahui pola zonasi vegetasi mangrove pada Kawasan Mangrove Bekas Tsunami Di Aceh Barat Selatan. Sejak terjadinya tsunami 26 Desember 2004 menyebabkan sebagian hutan rusak. Hal ini 
menyebabkan zonasi hutan mangrove telah berubah. Oleh karena itu kajian mengenai analisis zonasi ekosistem mangrove pada kawasan mangrove bekas tsunami di Aceh Barat Selatan perlu dilakukan.

\section{RUMUSAN MASALAH}

a) Bagaimanakah struktur komunitas vegetasi mangrove pada bekas tsunami di Aceh Barat Selatan?

b) Bagaimana pola zonasi vegetasi mangrove pada kawasan bebas tsunami di Aceh Barat Selatan?

\section{METODE PENELITIAN}

\subsection{Pengambilan Sampel}

Penelitian ini menggunakan metode survei dan teknik pengambilan sampel vegetasi dengan plot sampling. Data dianalisis untuk mengetahui kekayaan, kepadatan dan distribusi mangrove. Analisis pola zonasi menggunakan Analisis Pengelompokan(Cluster Analisys), untuk mengetahui besarnya kontribusi masingmasing spesies terhadap pengelompokan menggunakan analisis persentase kesamaan (Similarity Precentages).

\subsection{Prosedur Penelitian}

Pengambilan sampel vegetasi mangrove dengan cara penentuan stasiun, pada tiap stasiun dibuat 3 plot dengan masing-masing plot seluas $10 \times 10 \mathrm{~m}$, masingmasing plot diambil data vegetasi mangrove (jumlah spesies, jumlah individu tiap spesies, dan distribusi spesies). Ukuran plot $10 \mathrm{~m} \times 10 \mathrm{~m}$ untuk pohon dengan diameter $\geq 10 \mathrm{~cm}$, anakan pohon (tinggi $>1,5 \mathrm{~m}$ dengan diameter $1 \mathrm{~cm}-10 \mathrm{~cm}$ ) dengan ukuran plot $5 \mathrm{~m} \times 5 \mathrm{~m}$ dan semai (ketinggian $\leq 1,5 \mathrm{~m}$ atau diameter $<1$ $\mathrm{cm})$ dengan ukuran plot $1 \mathrm{~m} \times 1 \mathrm{~m}$. Setiap jenis vegetasi mangrove yang didapat diidentifikasi di Laboratorium berdasarkan buku karangan Kitamura et al. (1997), Noor et al. (2006) dan Giesen et al. (2006).

\subsection{Analisis Data}

Untuk mengetahui kondisi struktur komunitas vegetasi mangrove, kekayaan spesies, kepadatan, dan distribusi perlu dilakukan.

1. Kekayaan spesies (species richness) yaitu jumlah total spesies dalam suatu komunitas yang dihitung dengan menggunakan Indeks Margalef berdasarkan rumus dari Spellerberg (1991).

$$
D=\frac{S-1}{\log N}
$$

Keterangan :

$\mathrm{D}=$ Indeks Margalef

$\mathrm{S}=$ jumlah spesies

$\mathrm{N}=$ jumlah total spesies

2. Kepadatan merupakan jumlah individu per satuan luas atau volume berdasarkan rumus dari Brower et al. (1990).

$$
\text { Kepadatan }=\frac{\text { Jumlah } \text { individu suatu spesies }}{\text { Luas area }}
$$


3. Distribusi makrozoobentos dilakukan dengan menggunkan analisis variance berdasarkan rumus Spellerberg (1991).

$$
S^{2}=\frac{\sum_{n-1}^{n}(x i-x)^{2}}{n-1}
$$

Keterangan:

$\mathrm{S}^{2}$ : Variance Index

$\mathrm{n}:$ jumlah sampel

$x i$ : perbedaan nilai pada saat observasi

$x$ : rata-rata sampel

Analisa pola distribusi pada daerah penelitian dapat dilihat pada Tabel 1.1 (Spellerberg, 1991).

Tabel 1 Penetuan pola distribusi

\begin{tabular}{cl}
\hline Perbandingan rata-rata dan ragam $\left(\mathrm{S}^{2}\right)$ & \multicolumn{1}{c}{ Pola distribusi } \\
\hline $\mathrm{S}^{2}=0$ & Uniform (tersebar rata) \\
$\mathrm{S}^{2}=\bar{x}$ & Random (acak) \\
$\mathrm{S}^{2}>\bar{x}$ & Aggregate (mengelompok) \\
\hline
\end{tabular}

\subsection{Alat dan Bahan Penelitian}

Alat yang digunakan dalam penelitian meliputi perahu, Global Positioning System (GPS) digunakan untuk menentukan titik sampling. Meteran 100 m digunakan untuk pembuatan plot. Plastik digunakan untuk menyimpan sampel mangrove, Spidol digunakan untuk inventarisasi sampel, Soil tester digunakan untuk megukur $\mathrm{pH}$ tanah. Termometer digunakan untuk mengukur suhu air. Handrefraktosalinometer digunakan untuk mengukur salinitas. Pensil dan buku catatan digunakan untuk mencatat hal-hal yang dianggap perlu dicatat dalam penelitian. Kamera digunakan untuk mendokumentasikan penelitian. Pengarang buku identifikasi mangrove yang digunakan adalah Kitamura et al. (1997) dan Giesen et al. (2006).

\section{HASIL DAN PEMBAHASAN}

\subsection{Kekayaan Spesies}

Hasil penelitian kekayaan mangrove ditemukan dua spesies disemua stasiun yaitu Rhizophora apiculata dan Rhizophora mucronata. Kekayaan mangrove yang di temukan di setiap stasiun dapat di lihat Tabel 2.

Tabel 2 Kekayaan Mangrove di Setiap Stasiun

\begin{tabular}{cccccc}
\hline Spesies & \multicolumn{5}{c}{ Stasiun } \\
\cline { 2 - 6 } & SA1 & SA2 & SA3 & SA4 & SA5 \\
\hline Nipah & + & & & + & \\
Rhizophora apiculata & - & + & + & & + \\
Sonetaria alba & - & - & & & + \\
\hline
\end{tabular}

Vegetasi pada stasiun 1 hanya ditemukan tumbuhan nipah. Stasiun 2, 3 dan 3 hanya ditemukan satu jenis spesies yaitu Rhizophora apicula. Mangrove pada stasiun 5 ditemukan hanya satu spesies yaitu Sonetaria alba. Kekayaan mangrove di setiap stasiun relatif sama karena hutan mangrove pasca tsunami di Aceh Barat selatan ditanam dengan sengaja sehingga jenisnya lebih homogen. 


\subsection{Kerapatan Mangrove}

Kerapatan mangrove yang ditemukan di lokasi penelitian pada setiap stasiun menunjukkan bahwa stasiu 1 (3,33 individu/ha) lebih rapat dibanding yang lain, kemudian diikuti oleh stasiun 2 (44,00 individu/ha), stasiun 3 (84,33 individu/ha), stasiun 4 (34,67individu/ha), dan stasiun 5 (44,00 individu/ha) (Tabel 1..2).

Tabel 3 Kerapatan Mangrove di Setiap Stasiun/ha

\begin{tabular}{ccccccc}
\hline Spesies & SA1 & SA2 & SA3 & SA4 & SA5 & Jml Total \\
\hline Nipah & 3.33 & 0.00 & 38.33 & 0.00 & 0.00 & $\mathbf{4 1 . 6 6}$ \\
Rhizophora apiculata & 0.00 & 44.00 & 46.00 & 34.67 & 0.00 & $\mathbf{1 2 4 . 6 7}$ \\
Sonetaria alba & 0.00 & 0.00 & 0.00 & 0.00 & 44.00 & $\mathbf{4 4 . 0 0}$ \\
Kerapatan total tiap stasiun & $\mathbf{3 . 3 3}$ & $\mathbf{4 4 . 0 0}$ & $\mathbf{8 4 . 3 3}$ & $\mathbf{3 4 . 6 7}$ & $\mathbf{4 4 . 0 0}$ & $\mathbf{2 1 0 . 2 3}$ \\
\hline
\end{tabular}

Kerapatan total di setiap stasiun tertinggi ditemukan pada stasiun 3 sebesar 843,33 individu/ha, sedangkan kerapatan terendah terdapat di stasiun2 dan 5 sebesar 44.00 individu $/ \mathrm{m}^{2}$. Rhizopora apiculata memiliki kerapatan spesies tertinggi sebesar 124,67 individu/ha, sedangkan Nipah memiliki kerapatan jenis terendah sebesar 41,66 individu/ha.

\subsection{Distribusi Mangrove}

Pola distribusi dari masing-masing spesies menunjukkan bahwa gastropoda yang memiliki pola distribusi mengelompok adalah Ceritidhea alata, , Neritina violacea, Neritina zigzag. Gastropoda yang memiliki pola distribusi acak adalah Ceritidhea quadrata, Neritina lineate, Cassidulla aurisfelis, Cassidulla nucleus,_dan Littoraria carinifera (Tabel 1.3).

Tabel 4 Pola Distribusi Makrozoobentos

\begin{tabular}{lrrrr}
\hline Nipah & 284.19 & 8.27 & $\mathrm{~S}^{2}>\overline{\mathrm{x}}$ & Mengelompok \\
Rhizophora apiculata & 536.37 & 24.93 & $\mathrm{~S}^{2}>\overline{\mathrm{x}}$ & Mengelompok \\
Sonetaria alba & 387.20 & 8.80 & $\mathrm{~S}^{2}>\overline{\mathrm{x}}$ & Mengelompok \\
Keterangan : & & & & \\
$\mathrm{S}^{2}=$ Variance Indeks & & \\
$\bar{x} \quad=$ Rata-rata \\
Mangrove yang berada di lokasi penelitian mayoritas mengelompok. Pola \\
distribusi mengelompok disebabkan oleh adanya faktor pembatas terhadap keberadaan \\
suatu populasi. individu yang mengelompok disebabkan karena adanya keseragaman \\
habitat sehingga terjadi pengelompokkan di tempat yang mengandung makanan. \\
Pengelompokkan suatu spesies disebabkan karena adanya kecenderungan untuk \\
mempertahankan diri dari predator dan faktor-faktor lain yang tidak menguntungkan \\
(Nybakken, 1988).
\end{tabular}

\section{KESIMPULAN DAN SARAN}

\subsection{Kesimpulan}

Berdasarkan hasil penelitian, dapat disimpulkan bahwa jumlah spesies yang ditemukan dalam lokasi penelitian ada 3 yaitu Nipah, Rhizopora apiculata dan Sonneratia alba.Zonasi mangrove yang berada di lokasi penelitian terdiri dari tiga zonasi yaitu zona Nipah yaitu zona yang paling dekat dengan daratan, kemudian zona Rhizopora apiculata dan zona Sonneratia alba. Pada masing-masing zona terlihat persebarannya mengelompok. 


\subsection{Saran}

Pemerintah dan masyarakat perlu menjaga keseimbangan hutan mangrove dengan cara menjaga zonasi mangrove yang utuh.

\section{DAFTAR PUSTAKA}

Brower, J.E., J.H. Zar, and C.N. von Ende. 1990. Field and Laboratory Methods for General Ecology. WCB Publisher, Dubuque.

Giesen, W., S. Wullffraat, M. Zieren., and L. Scholten. 2006. Mangrove Guide Book For Southeast Asia. FAO and Wetlands International, Bangkok.

Hilmi, E. 2005. Ekologi Mangrove Pendekatan Karakteristik, Statistik dan Analisis Sistem Bagi Suatu Ekosistem. PSPK, UNSOED. Purwokerto.

Kitamura, S., C. Anwar, A. Chaniago., and S. Baba. 1997. Handbook of Mangrove in Indonesia: Bali and Lombok. International Society for Mangrove Ecosystem, Denpasar.

Noor, Y.R., M. Khazali, dan N.N. Suryadiputra. 2006. Panduan Pengenalan Mangrove di Indonesia. Wetlands International Indonesia Programe, Bogor.

Nybakken, J.W. 1992. Biologi Laut Suatu Pendekatan Ekologi. PT. Gramedia Jakarta.

Spellerberg, I.F. 1991. Monitoring Ecological Change. Cambridge University Press, Cambridge. 